\title{
NARRATIVE TEXT
}

\author{
By: Rayendriani Fahmei Lubis ${ }^{1}$
}

\begin{abstract}
ABSTRAK
Tulisan ini berkaitan tentang proses dan tata cara menulis suatu jenis teks. Di dalam tulisan ini, penulis bermaksud membahas salah satu jenis teks yang ada, yaitu Naratif Teks (Narrative Text). Tujuan tulisan ini adalah untuk mengetahui dan memahami bagaimana proses atau tata cara serta komponen-komponen (Generic Stucture) atau tata bahasa (Language Features) yang terdapat di dalam tulisan Naratif. Dengan mengetahui dan memahami semua yang berkaitan tentang tata cara dan komponenkomponen penulisan tersebut, maka diharapkan tidak ada lagi kerancuan atau kesalahan yang terdapat di dalam tulisan, khususnya pada penulisan Naratif teks.

Key Words: Narrative Text, Generic Stucture, Types of Narrative Text, The Language Elements of Narrative and Techniques in Teaching Narrative Text.
\end{abstract}

\section{A. INTRODUCTION}

English is an introduction language spoken in international event and is used as the medium of information flow on science, technology, and culture as well. As we are in developing country we should try to be able to speak English to make relationship with other country in the world so that we can master the science, technology and culture in the world. So we can face the competition in the global era. By mastering English, it is easier for us to make a good relationship with other countries.

In Indonesia, English is taught in junior high school and senior high school, even in elementry school. Studying English is not a new thing for the students of senior high school before. Although English is not the new thing for Senior high school students, in fact they still have many difficulties in studying English. As we know that English is not the Indonesian native language. It is difficult for the students to remember all the words in English and to understand when someone speaking English.

\footnotetext{
${ }^{1}$ The Chief of English Education Department Lecturer of Tarbiyah and Teacher Training Faculty (FTIK), Institut for Islamic Studies (IAIN) Padangsidimpuan.
} 
The language skill to be achieved is divided in to two parts of language function, namely, oral and written English as a means of communication. In this case listening and speaking are oral language; reading and writing are written language. However for the students the written one is the most difficult skill of language.

Writing is one of difficult subjects at school. So the teacher must create the subject so that the students can study the subject easily. Besides, the kinds of the text can also be important in teaching English in order to make the writing teaching successful. To select the appropriate texts, the teacher must consider the characteristics of the students, which directly related to the learning process.

In the teaching and learning process of writing, the teacher have an important role. John states that:

"Teacher's role is to help students develop viable strategies for getting started (finding topics, generating ideas and information, focusing and planning, structure and procedure), for drafting, (encouraging multiple drafts of redaing), for revising (adding, deleting, modifying and rearranging ideas), and for editing (attending to vocabulary, sentence, structure, grammar, and mechanics)."2

There are many kinds of texts that can be used such as narrative, descriptive, explanation, recount, information, report, exposition, and argumentation. They are very useful for the teacher to achieve the instructional goals of teaching learning process and they can also be interesting for the students.

\section{B. REVIEW OF RELATED LITERATURE}

\section{General Concept of Narrative Texts}

English must be learned as a second lenguage that is the major language spoken in the community or the language of instruction in the schools where English is taught as a foreign language. To make the students feel enjoyable and pleasure in learning writing, teachers must select interesting writing text to teach writing.

\footnotetext{
${ }^{2}$ M. Ann John, Text, Role and Context, (Australia: Cambridge University Press, 1997), p. 12.
} 
Meyers states that narrative is one of the most powerful ways of communicating with others. ${ }^{3}$ A good written story lets your reader response to some event in your life as if it were own. They not only understand the event, but they can almost feel it. The action, details, and dialogue put the readers in these seem and make it happen for them. Moreover, Anderson states that narrative is a piece of text tells a story and, in doing so, entertains or informs the reader or listener. ${ }^{4}$

A. S. Hornby in Oxford Advanced Learner's Dictionary defines "Narrative is a description of events, especially in a novel or story, the act or process of feeling a story". 5 It similarly with John Langan says, "Narration is a writer tells the story of something that happened" through narrative, we make statement clear by relating in detail something that has happened to us". 6 According to Otong Setiawan, "Narrative is kinds of text about story of legend and resolution to amuse and to give entertain to readers". 7 On the other hand, according to Pardiyono, "Narrative is a story talk the past activities or events which order to problematic and to give lesson to readers". ${ }^{8}$ In Curriculum 2004, narrative text is defined as a text which function is to amuse, entertain, and to deal with actual or various experience in different ways. Narrative deals with problematic event lead to a crisis or turning point of some kind in turn finds a resolution.

From the definition above, it is concluded that narrative story is a story tells about something interesting that has purpose to amuse, entertain or the readers. The using narrative when you tell a friend about something interesting that happen to you at work or at school, when you tell someone a joke. Anderson states that a good narrative uses wird to paint a picture in our mind of:

\footnotetext{
${ }^{3}$ Allan Meyers, Gateways to Academic Writing: Effective Sentences Paragraph and Essay, (New York: Longman, 2005), p. 52.

${ }^{4}$ Mark Anderson, Text Type in English 2, (Australia: Mackmillan, 1997), p. 8.

${ }^{5}$ A. S. Hornby, Oxford Advanced Learner's Dictionary of Current English, (London: University Press, 1995), p. 502.

${ }^{6}$ John Langan, Collage Writing Skills With Readings, (New York: MC Graw-Mill Book Company, 1986), p. 111.

${ }^{7}$ Otong Setiawan Djuharie, Genre, (Bandung: Yrama Widya, 2007), p. 41.

${ }^{8}$ Pardiyono, Teaching Genre-Based Writing, (Yogyakarta: Andi Offiset, 2007), p. 94.
} 
a. What characters look like (their experience),

b. Where the action is taking place (the setting),

c. How things are happening (the action). ${ }^{9}$

The characteistics of nattative texts among others:

a. It tells us about a story of event or events.

b. The events are usually arranged in chronological order- that is, in the order in which they occurred in time.

c. The narrator has a purpose in mind in telling the story. There are some points the narrator wishes to make, or some impression he or she wishes to convey to the reader. Therefore, the details of tha narrative are carrefully selected for purpose.

Narration is telling a story. And to be interesting, a good story must must have interesting content. At should tell us about an event your audience would find enganging. You might even thing of your narrative as a movie in which readers see people in action and hear them speak. Therefore, it should be detailed and clear, with even arranged in order in which they happened or in some other effective ways you should use for narrative that achieves all of the followings goals:

a. It is unified, with al the action a developing central idea.

b. It is interesting, it draws the writer into the action and makes them feel as if they are observing and listening to the events.

c. It introduces the four ws of a setting- who, what, where, and when- within the context of the action.

d. It is coherent, transinsition indicates changes in time, location, and characters.

e. It begins at the beginning and edn of the end. That is, the narrative follows a chronological order- with events happening in a time sequence.

f. It builds towards a climax. Thi is the moment of most tension or surprise a time when the ending is revealed or the importance of events becomes clear.

The language features usually found in narrative texts are:

a. Specific characters.

b. Time words that connect to tell when they occur.

c. Verbs to show the action that occur in the story.

\footnotetext{
${ }^{9}$ Ibid., p. 14.
} 
d. Descriptive words to portray tha chracter and setting. ${ }^{10}$

\section{Generic Structure of Narrative Texts}

Neo states that a narrative has a structure, a shape or a pattern. It can be represented graphically in this way.

Climax

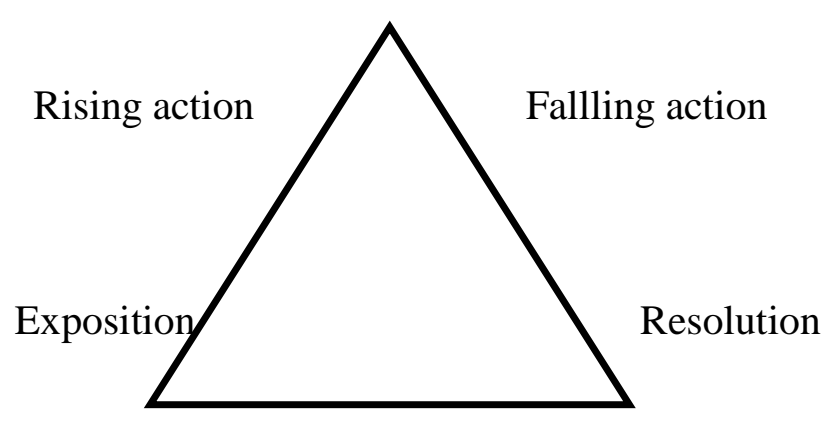

That picture is known as the Freitag triangle. The idea of the Freitag triangle is to serve as akind of blue print or map which can be used to guide us systematically ijnour writing. The Freitag triangle consists of:

a. The composition, it establishes the characters and situation.

b. Rising action, it refers to a series of complication leads to the climax.

c. The climax is the critical moment when problem/ conflics demand something to be done about them.

d. Felling action is the moment away from the highest peak of excitemen.

e. The reolution consists of the result or outcome. ${ }^{11}$

On the other hand, Anderson states that the steps for constructing a narrative are:

a. Orientation/ exposition

The readers are introduced to the main characters and possibly some minor characters. Some indication is generally given of where the action is located and when it is taking place.

b. Complication/ rising action

The complication is pushed along by a serious of events, during which we usually expect some sort of complication or problem to arise. It just would not be so interesting if something unexpcted did not happen. This

\footnotetext{
${ }^{10}$ Ibid., p. 15.

${ }^{11}$ Ernest Neo, Narrative for 'O' Level. (Malaysia: Longman, 2005), p. 2.
} 
complication will involve tha main charcters and oven serves to (temporally) toward them from reaching their goal.

c. Sequence of event? Climax

This is where the narrator tells how the character reacts to the comlication. It includes their feeling and what they do. The event can be told in chronological order (the order in which they happen) or with flashback. The audiens is given the narrator's poiunt of view.

d. Resolution/ falling action

In this part, the implication may be resolved for better or worse, but it is rarely left completely unresolved (although this is of course possible in certain tyoes of narrative which leaves us wondering 'How did it end"?)

e. Reorientation $\rightarrow$ It is an optional closure of event. ${ }^{12}$

\section{Types of Narrative Texts}

There many different types of narrative texts, among others:
a. Humor
b. Romance
c. Crime
d. Real Life Fiction
e. Theoritical fiction
f. Mystery
g. Fantasy
h. Science Fiction
i. Diary Novels
j. Adventure $^{13}$

There can be a combination of narratives within each of this different types. Sometimes, the term genre is used for the type of narrative. A genre is some kind of a category. ${ }^{14}$ The notion of genre is to help to generate story ideas. Here are some examples of the different type (or genre) of narrative showing typical features:

\footnotetext{
${ }^{12}$ Mark Anderson, Op. Cit., p. 8.

${ }^{13}$ Ernest Neo, Op. Cit., p. 58.

${ }^{14}$ Ibid., p. 8.
} 
a. Humor

A humorous narrative is one of that aims to make audience laugh as a part of telling story. Here is typical structure:

1) Orientation: the narrator tells the funny characters names in unusual setting.

2) Complication: in this part, something crazy happen.

3) Sequence of event: there are many imaginative ideas here funny things said by characters and extraordinary things happening to ordinary people.

4) Resolution: All's well that end well. ${ }^{15}$

b. Romance

The romance narrative typically tells of two lovers who overcome difficulties to end up together. Here are the usual fetures:

1) Orientation: it contains hunk male and female who is looking for love, exotic setting, sun set, beaches, and moonlight.

2) Complication: boy meets girl.

3) Sequence of event: it contains the development relationship, jealously, love, hurt, pian, warm, sharing, and overcoming problems.

4) Resolution: boy gets girl, marry and live happy ever aafter. ${ }^{16}$

c. Historical Feature

Here are the feature of a typical historical fiction text:

1) Orientation: a setting in the past and description of a period in history.

2) Complication: good meets evil.

3) Sequence of event: action related to a period in history, character's lives affected by the events of history, description of live at the time.

\footnotetext{
${ }^{15} I b i d .$, p. 58.

${ }^{16} I$ Ibid., p. 59.
} 
4) Resolution : characters survive the chaos of the time (for example, the war ends). ${ }^{17}$

d. The Diary Novel

This type of narrative has the text presented like diary entries. Here are the features of a typical diary- novel:

1) Orientation: main character is the narrator. Time setting is given by diary entries.

2) Complication: given one of diary entries. It can be related to romance, adventure, humor, mystery, or other type.

3) Sequence of event: diary entries tell of feelings, hopes, and happening.

4) Reorientation: the narrator tells what happens to solve the complication. $^{18}$

e. Fantasy

Below are the features of a typical fantasy narrative:

1) Orientation: setting may be in another dimension with goals, witches, wizard, and so son. Hero who may has magical power.

2) Complication: evil forces affect the goodies.

3) Sequence of event: use of magic. Action includes elves, dragons and mystical beasts, heroism.

4) Resolution: God defeats evil forces. ${ }^{19}$

\section{f. Science Fiction}

Science fiction narratives ese the setting involving science and technology. Here are the typical features of the text type:

1) Orientation: a feature setting and a world with technology.

2) Complication: an evil force threatens the world.

3) Sequence of event: imaginative description. Action involves technology, science, and super invention.

\footnotetext{
${ }^{17}$ Ibid., p. 59.

${ }^{18}$ Ibid., p. 60.

${ }^{19}$ Ibid., p. 60.
} 
4) Resolution: good defeats evil.

5) Coda: take care that science is used for good, not evil. ${ }^{20}$

\section{The Language Elements of Narrative}

According to Otong Setiawan Djuharie, the language elements use in writing narrative paragraph are nouns, individual participant, past tense, conjunction, action verb, and saying verb.

a. Noun is a word used as the name of a person, place or thing. ${ }^{21}$

Budi is our teacher

There is a table in the class

I saw a man in the market

b. Individual participant

Individual participant means that the subject who takes part in a situation or the story of specific subject. ${ }^{22}$ Such as story about snow white, Prophet Muhammad, MalinKundang.

c. Past Tense

The simple past is used of a complete action that happened at one specific time in the past. ${ }^{23}$ According to Betty Schrampfer Azar, "Simple Past Tense is used to talk about activities or situations that began and ended at a particular time in the past." ${ }^{24}$ Meanwhile, according to Jayanthi Dakshina Murthy, "Simple Past Tense is when a verb is used to shown that an action was completed. ${ }^{25}$ So, Simple Past Tense is a sentence or story as do past thus, can see of used verb and adverb of sentences.

d. Conjunction

Conjunction is a word which used to join one word to another word, or one sentence to another sentence. There are two types of

\footnotetext{
${ }^{20}$ Ibid., p. 61.

${ }^{21}$ Wren and Martin, High School English Grammar and Composition, (New Delhi: S. Chan \& Company Ltd, 1966), p. 5.

${ }^{22}$ Otong Setiawan Djuharie, Genre, (Bandung: Yrama Widya, 2007), p. 25.

${ }^{23}$ Cliffs, Toefl, (India: Dream Land, 2005), p. 59. 1993), p. 32.

${ }^{24}$ Betty Schrampfer Azar, Fundamentals of English Grammar, (Jakarta: Bina Rupa Aksara, p. 151 .

${ }^{25}$ Jayanthi Dakshina Murty, Contemporary English Grammar, (New Delhi: Book Palace. 2003),
} 
conjunction subordinating conjunction. ${ }^{26}$ According to Slamet Riyanto $\mathrm{dkk}$, conjunctions are words that are used to connect words or a group of words or sentence. ${ }^{27}$ So, conjunction is the word as function combine a word or sentences.

e. Action verb

The action verb divided into two forms. ${ }^{28}$

1) Regular verb is a verb which has a normal inflection or normally added by "ed" or "d" to the infinitive.

2) Irregular verb is a verb which does not have a normal inflection or normally added by "ed" d" to the infinitive form.

According to Betty Schrampfer Azar, the action verb divided in two forms: ${ }^{29}$

1) Regular verb: the simple past and past participle and in-ed.

Example:

$\begin{array}{lll}\text { Listen } & \text { listened } & \text { listened } \\ \text { Study } & \text { studied } & \text { studied } \\ \text { Stop } & \text { stopped } & \text { stopped }\end{array}$

2) Irregular verb: the simple past and past participle do not end in-ed.

Example:

$\begin{array}{lll}\text { Swim } & \text { swam } & \text { swum } \\ \text { Find } & \text { found } & \text { found } \\ \text { Break } & \text { broke } & \text { broken }\end{array}$

f. Saying verb

It is about verb which to show the report or say such as said, told promised, thought, understood. ${ }^{30}$ According to Jayanthi Dakshina Murthy, "Verb is described as a word which is used to indicate an actions, a state of

\footnotetext{
${ }^{26}$ Wren and Martin, Op. Cit., p. 151-153.

${ }^{27}$ Slamet Riyantodkk, A Complete Course to the Toeic Test, (Jogjakarta: Pustaka Pelajar, 2008),

${ }^{28}$ Ahmad Kardimin, Fundamental English Grammar, (Jakarta: Pustaka Pelajar, 2009), p. 30.

${ }^{29}$ Betty Schrampfer Azar, Op. Cit.,p. 41.

${ }^{30}$ Otong Setiawan Djuharie, Op. Cit., p. 41.
} p. 80. 
being of existence or possession." ${ }^{31}$ Example: bought, save, handed, lent, offered, paid, played, promised, showed, sang, made, told, sent, sold, got.

\section{Technique in Teaching Narrative}

The writing of narrative as an activity can ba down into four separate parts. Each of these four parts will be single paragraph. The paragraph shiould be arranged as follows:

a. The first paragraph should tell something about the job. What kind of work were you doing? Where was the work performed? What were your working conditions like?

b. The second paragraph should describe the conflict. What was its source? Was it a conflict over two different attitudes toward work, two different ways of doing the same job, two different personalities?

c. The third paragraph should tell how the conflict was resolved. Was it resolved fairly or unfairly, by whom?

d. The fourth pargraph should give the moral of the story. What did you learn from the experience? Were you able to apply what you learned to other experiences in your life? ${ }^{32}$

\footnotetext{
${ }^{31}$ Jayanthi Dakshina Murthy, Op. Cit, p. 86-87.

${ }^{32}$ M. Ann John, Op. Cit., p. 27.
} 


\section{The Example of Narrative Text}

\section{Lake Toba}

Once upon time in Batakland lived a fisherman named Bhatara Guru Salaha. He caught a fish that could talk one day, that could turn into a beautiful woman whose anger could shake the earth and makethe volcano erupt.

As a tough fisherman, he went fishing every morning. One day, he caught an unusual fish in his old fishing net. It was an unusual fish because it could talk like human. What made him more suprised was that the fish asked him to set it free back to the river.

He could do nothing except to agree, and soon he set it free back to the river. As soon as he set the fish free back to the river, it changed into a beautiful woman. She was with long black hair and big round eyes. "She was really beautiful," Sahala thought. He finally fell in love with her, and asked her to marry him. He promised to be faithful and would take care of her day and night. The woman agreed to marry him with one very important promise. She asked him not to let anyone know that she was once a fish. Sahala agreed and promised to do so, and would always hold up the deal.

They were happily married, and got two beautiful smart daughters. As a fisherman to live his happy days, $\checkmark$ Sahala went fishing every morning with his daughters who used to bring him food and drink very much while fishing. Unfortunately, his two daughters really made he was very unhappy one day. He was very mad to them. They ate up the food and drink instead of serving them to his beloved father. As he was so upset and got very angry, his uncontrolled emotion blew up and came out dirty words from his mouth. He shouted, "You behaved exactly like the daughters of a fish!"

The two daugthers didn't understand what their father had just talked about. Thay didn't understand why he said like that to them. They soon went home and told everything to their mother. Their mother was very annoyed and didn't feel too well with the situation. Sahala came home to explain everything and apologized to his wife. He realized everything about what he had just said to his daughters and begged to her pardon. Unfortunately, it seemed his crying didn't work. His wife didn't care too much to his apology. She could not forgive Sahala. 


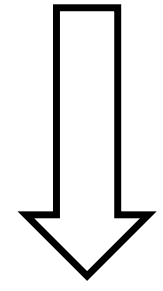

Coda

Suddenly, another unusual thing occurred! She trembled severely, and everything around her was shaking. The earth began to shake and volcano began to erupt. The earth began to crack down to form a large hole. The hole grew larger and larger, and filled in it with much water. The large hole grew up to form a lake, and it was then called LAKE TOBA.

It is very famous as a place of interest for domestic and foreign visitor up to now. It has lovely view and natural beauty. This legend is still well known for people of this country and is still held up as one of the famous folk tales of the nation. ${ }^{33}$

\section{CONCLUSION}

The writer has some concluding from all of explanation above about narrative text; they involve general concept of narrative text, The language features usually found in narrative texts, generic structure of narrative text, the types of narrative text and technique in teaching narrative text. They are below:

1. Narrative text is a story tells about something interesting that has purpose to amuse, entertain or the readers. The using narrative when you tell a friend about something interesting that happen to you at work or at school, when you tell someone a joke.

2. The language features usually found in narrative texts, they are specific characters, time words that connect to tell when they occur, verbs to show the action that occur in the story and descriptive words to portray the character and setting.

3. Generic structure of narrative text are the composition, it establishes the characters and situation, rising action, it refers to a series of complication leads to the climax, the climax is the critical moment when problem/ demand something to be done about them, felling action is the moment away from the highest peak of excitemen, the relution consists of the result or outcome.

4. The types of narrative text are humor, romance, crime, real life fiction, theoretical fiction, mystery, fantasy, science fiction, diary novels and adventure.

${ }^{33}$ Pardiyano, Pasti Bisa! Teaching Genre-Based Writing Metode Mengajar Writing Berbasis Genre Secara Efektif, (Yogyakarta: Andi, 2007), p. 105. 
5. Techniques in teaching narrative text are the first paragraph should tell something about the job, the second paragraph should describe the conflict, the third paragraph should tell how the conflict was resolved.

\section{REFERENCES}

Anderson, Mark. 1997. Text Type in English 2. Australia: Mackmillan.

Azar, Betty Schrampfer. 1993. Fundamentals of English Grammar. Jakarta: Bina Rupa Aksara.

Cliffs. 2005. Toefl. India: Dream Land.

Djuharie, Otong Setiawan. 2007. Genre. Bandung: Yrama Widya.

John, Ann. M. 1997. Text, Role and Context. Australia: Cambridge University Press.

Kardimin, Ahmad. 2009. Fundamental English Grammar. Jakarta: Pustaka Pelajar.

Martin and Wren. 1966. High School English Grammar and Composition. New Delhi: S. Chan \& Company Ltd.

Meyers, Allan. 2005. Gateways to Academic Writing: Effective Sentences Paragraph and Essay. New York: Longman.

Murty, Jayanthi Dakshina. 2003. Contemporary English Grammar. New Delhi: Book Palace.

Neo, Ernest. 2005. Narrative for 'O’ Level. Malaysia: Longman.

Pardiyano. 2007. Pasti Bisa! Teaching Genre-Based Writing Metode Mengajar Writing Berbasis Genre Secara Efektif. Yogyakarta: Andi.

Riyanto, Slamet, dkk. 2008. A Complete Course to the Toeic Test, Jogjakarta: Pustaka Pelajar. 